\title{
Esiste un'identità europea?
}

\section{Franco Cardini}

Storicamente, 2 (2006).

ISSN: 1825-411X. Art. no. 68. DOI: 10.12977/stor541

19 ottobre 2006

\section{Prof. Franco Cardini}

(Università degli Studi di Firenze)

Esiste un'identità europea?

(conferenza)

[[figure]]figures/2006/Gentile_1/Gentile_1_2006_01.jpg[[/figure]] 